\title{
Editorial
}

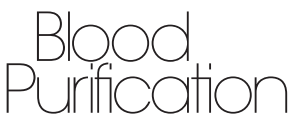

\section{Coronavirus Epidemic and Extracorporeal Therapies in Intensive Care: si vis pacem para bellum}

\author{
Claudio Ronco ${ }^{a-c}$ Thiago Reis ${ }^{b, d}$ Silvia De Rosa ${ }^{b, e}$

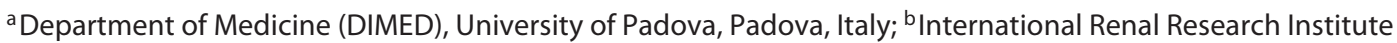 \\ Vicenza, Vicenza, Italy; ' Department of Nephrology, Dialysis and Transplantation, San Bortolo Hospital, Vicenza, Italy; \\ ${ }^{d}$ Clinica de Doenças Renais de Brasilia, Brasilia, Brazil; ' Intensive Care Unit, San Bortolo Hospital, Vicenza, Italy
}

The worldwide outbreak of coronavirus disease 2019 (COVID-19) has demonstrated that we are all part of a small world where diffusion of contagious diseases is inevitable [1]. Although the new coronavirus originated in Wuhan seems to present lower lethality compared to previous epidemic outbreaks from other coronaviruses, its capacity of diffusion has been phenomenal [2,3]. One infected individual may transmit the virus to 2 or 3 others [4]. Of note, screening based on symptoms and signs is ineffective and asymptomatic persons can spread the disease [5]. In the very early phases, before this wide diffusion of the virus, a call to action was published in Lancet Respiratory Medicine [6] underlining the need of alertness for zoonotic virus infections crossing species and infecting human populations [7]. In particular, recommendation was made to prepare intensive care teams to deliver extracorporeal organ support (ECOS) therapies in infected patients whose pulmonary syndromes are particularly severe [8]. Once again, despite previous experiences presented higher incidence of severe complications and lethality, the current outbreak still requires intensive care for $5 \%$ of the infected population. Among those critically ill patients, the mortality rate is $49 \%$. Even with the specific tropism for airway epithelial cells, the infection seems to be weak in humans and transmission is likely to occur only when lower respiratory tract disease develops. COVID-19 causes mild flu-like symptoms or even no symptoms in the majority of the patients [3]. Coronaviruses bind to receptors such as angiotensin-converting enzyme 2 . Angiotensin-converting enzyme 2 is present in the epithelia of the lung, small intestine, colon, and biliary tract. In fact, viral nucleic acids were found in stools and anal swabs of patients diagnosed with COVID-19 infection [9]. In a cohort of COVID-19-infected patients from Singapore, half (4 out of 8) of patients tested had the virus detected in stools [10]. This might explain liver dysfunction, diarrhea, nausea, and vomiting that occurred in patients with pneumonia, namely, the gut-lung crosstalk $[8,11]$.

In a Chinese group of patients with pneumonia caused by COVID-19, 23\% were admitted to intensive care unit (ICU), 17\% had acute respiratory distress syndrome, and $11 \%$ died [11]. Major preventive measures have been undertaken in specific areas where the incidence was significantly higher, to limit the diffusion of the virus [7]. Despite those measures, the requirement of ICU services and stations still has dramatically increased. Personal communications and early reports mostly coming from China suggest that $67 \%$ of severely ill COVID-19 patients may present with additional organ dysfunction syndromes $[8$, $11,12]$. This has been, at least in part, related to a sepsislike syndrome induced by high level of circulating cytokines $[2,12]$. In such circumstances, while pulmonary

\begin{tabular}{ll}
\hline KARGER & (c) 2020 The Author(s) \\
& Published by S. Karger AG, Basel \\
karger@karger.com & This article is licensed under the Creative Commons Attribution- \\
www.karger.com/bpu & NonCommercial-NoDerivatives 4.0 International License (CC BY- \\
NC-ND) (http://www.karger.com/Services/OpenAccessLicense). \\
Usage and distribution for commercial purposes as well as any dis- \\
tribution of modified material requires written permission.
\end{tabular}

Claudio Ronco, MD

Department of Nephrology, Dialysis and Transplantation San Bortolo Hospital

Viale Rodolfi, 37, IT-36100 Vicenza (Italy)

E-Mail cronco@goldnet.it 
exchanges are compromised and dominate the clinical scenario, acute kidney injury and heart and liver dysfunction may also become evident $[8,12-14]$. Cytokine storm may be induced by a superimposed septic syndrome or by the direct effect of the virus on the infected host. In the past, the experience matured with H1N1 influenza, SARS, and MERS has suggested that the severity of illness depended on comorbidities and the immune-competence of the individual. In severe situations, however, an uncontrolled inflammatory state or a subsequent/simultaneous immune-paralysis is the direct consequence of endocrine effects of pro- and anti-inflammatory cytokines spilled over into the systemic circulation. Of special interest, in a retrospective analysis of a German cohort [15] of 25 critically ill H1N1-infected patients, the prevalence of virusassociated hemophagocytic syndrome (VAHS) was 36\%. All patients with the syndrome had received extracorporeal membrane oxygenation (ECMO). ECMO could have been a trigger or an amplifier of cytokine activation. The pathogenesis of VAHS involves excessive production of interferon gamma and interleukin-2 [16]. VAHS itself is a prototype of a cytokine storm syndrome. In our present experience in San Bortolo Hospital, all our 4 COVID-19 critically ill patients have hyperferritinemia, raising awareness of VAHS as a differential diagnosis.

In organ dysfunction syndromes when pharmacological treatment is simply not available or efficacious, mechanical ventilation and hemodynamic support seem to be the only possible therapeutic strategy [17]. However, extracorporeal therapies such as hemofiltration or hemoperfusion (HP) offer a new possibility to support different organs in a multiple organ dysfunction condition. Using specific extracorporeal circuits and devices, heart, lungs, kidneys, and liver can be partially replaced or at least sustained during the severe phase of the syndrome. The concept is known as ECOS [18-20]. The most important technique in these cases is the ECMO mostly applied in venovenous mode [21-23]. Furthermore, extracorporeal $\mathrm{CO}_{2}$ removal is another option that can be performed in less severe cases to facilitate a less invasive and traumatic mechanical ventilation [24]. Although acute kidney injury in these patients is not common, continuous renal replacement therapies may offer in conditions of mild to severe kidney dysfunction a significant support for solute and fluid control. The same is true for left ventricular assist devices in case of refractory heart failure or albumin dialysis and HP in case of liver dysfunction and hyperbilirubinemia [25]. However, according to information collected from Chinese colleagues who faced a large proportion of patients with complicated COVID-19 syndromes in their
ICUs, a significant benefit seems to have been obtained with the use of direct HP with cartridges containing highly biocompatible sorbents and microporous resins [26]. Such therapies, designed to remove the excess of circulating cytokines, seem to have displayed a remarkable benefit in terms of hemodynamic support and organ function recovery [2]. The suggested scheme of application of HA380 cartridges (Jafron Biomedical Co., China) was 2-1-1, that is, 2 units utilized for $12 \mathrm{~h}$ in the first $24 \mathrm{~h}$ and 1 unit per day utilized for $24 \mathrm{~h}$ in the following 2 days. In Europe, we had matured some experience with the use of Cytosorb ${ }^{\circledR}$ car- $^{-}$ tridges (CytoSorbents Corporation, NJ, USA), exactly for the same purpose of controlling deadly inflammation in critically ill and cardiac surgery patients $[27,28]$. This approach may be just one of many others [29] utilizing extracorporeal therapies in these severe syndromes and will require scientific validation once the emergency of the current epidemic will be over. The suggested mechanism is the nonspecific removal of the peaks of the circulating cytokines both in the pro- and in the anti-inflammatory side. This is consistent with the "peak concentration hypothesis" suggested some time ago [30]. In presence of our inability to obtain instantaneous monitoring of biological levels of cytokines, the reasonable approach is to promote a nonspecific removal assuming that those cytokines with the highest concentration will be removed in higher amount (Fig. 1) [31]. This would facilitate a return to a less severe derangement of the immune system and to an improved level of the immunological response of the host. The same concept has been expressed by the "cytokinetic model." In this theory, the reduction of circulating levels of cytokines may allow the immune system of the patient to redirect the immunocompetent cells to the source or site of inflammation [32]. We warn users of these techniques that together with the removal of cytokines, some drugs and antibiotics like vancomycin are also removed. In vitro models proved that [33]. In this case, a specific adjustment of antibiotic dosage in patients with bacterial infections should be carefully planned. Another adjunctive potential extracorporeal therapy is lectin affinity plasmapheresis for coronavirus trapping. Blood runs into a plasma filter, and the filtered plasma containing viral copies passes through a matrix of lectins. There is a high affinity between the viral envelope and lectins. Likewise, some viral copies are captured and the viremia is reduced [34]. This therapy should be further explored and validated.

The main message the present editorial tries to convey is that the ICU staff and treating physicians should be familiar with the concept that extracorporeal therapies represent today an important strategy in critically ill pa- 

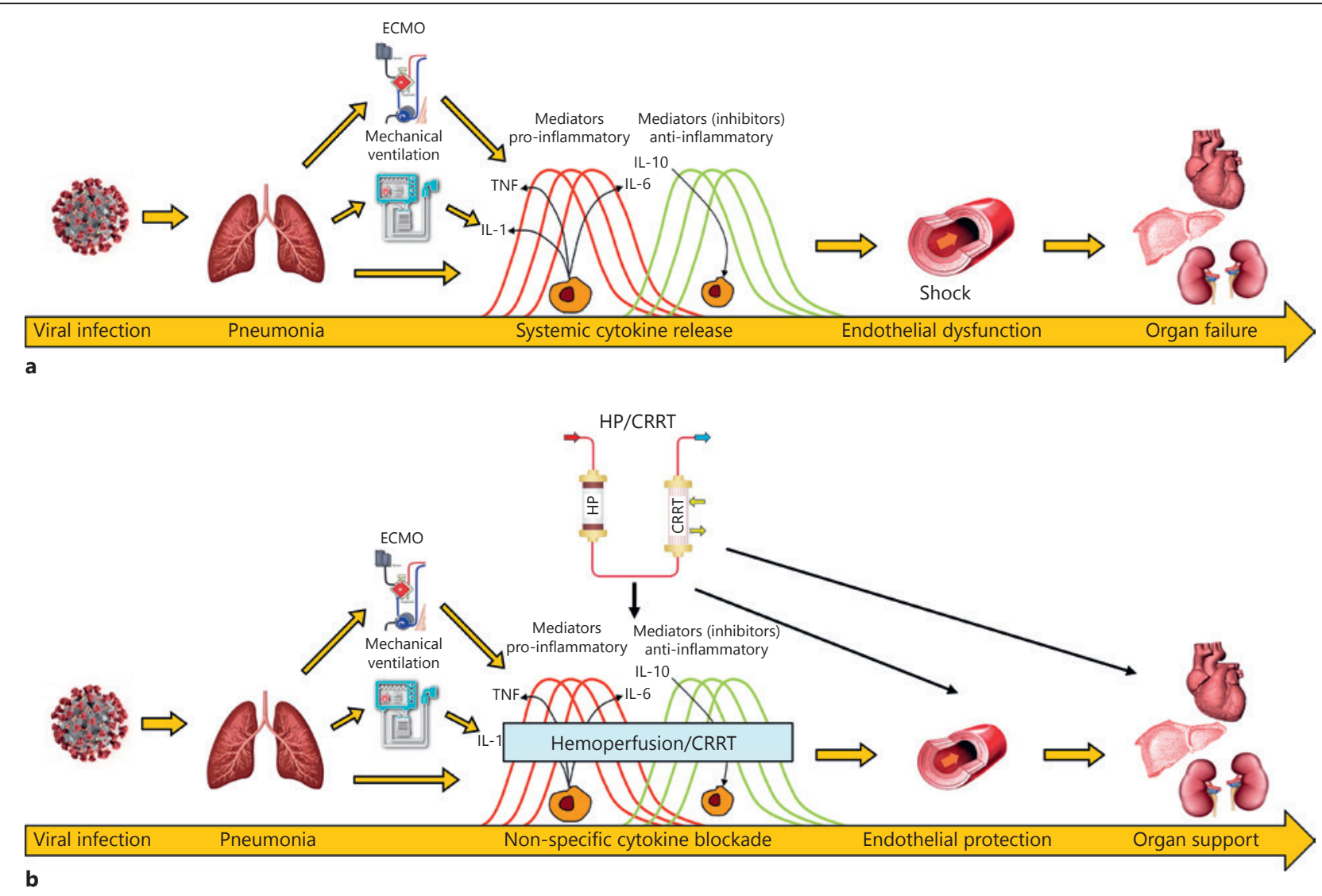

Fig. 1. a After a viral infection, a percentage of patients suffer from severe pneumonia. Such patients may have a systemic cytokine release due to the illness itself, to the mechanical ventilationassociated lung injury, and to the extracorporeal membrane oxygenation. This will induce endothelial dysfunction and consequent organ failure. $\mathbf{b}$ The application of HP may contribute to reduce the burden of cytokines cutting the peaks in a nonspecific way, re-

tients with multiple organ dysfunction. Training and research should be planned to further develop skills and knowledge in this area where new membrane separation processes and adsorption techniques appear to be a new frontier in fighting the so-called "cytokine storm syndrome." We will need to increase awareness of the basic principles, to study mechanisms, to optimize prescription and delivery of different techniques. We need to stimulate research and data collection to create sufficient scientific evidence. We need to prepare for the uncertain future where the frequency of these crises will be probably increasing [4]. We must retool ourselves with new strategies and new therapies, and among those, new ECOS therapies. As the ancients used to say: "Si vis pacem, para bellum," if you want peace, get prepared to war.

Coronavirus Epidemic and Extracorporeal Therapies in Intensive Care storing at least in part immune-homeostasis. When hemoperfusion is combined with continuous renal replacement therapies (HP/CRRT), the effect can be further amplified and the additional task of organ support can be accomplished. TNF, tumor necrosis factor; IL, interleukin; HP, hemoperfusion; CRRT, continuous renal replacement therapy; ECMO, extracorporeal membrane oxygenation.

\section{Acknowledgment}

There are no acknowledgments to declare.

\section{Disclosure Statement}

The authors have no conflicts of interest to declare.

\section{Funding Sources}

There are no funding sources to declare.

\section{Author Contributions}

All authors contributed equally to the manuscript and approved submission. 


\section{References}

1 World Health Organization. Global Surveillance For Human Infection with Coronavirus Disease (covid-19) Interim guidance 27 February 2020 [cited 2020 Mar 4]. Available from: https://www.who.int/publications-detail/global-surveillance-for-humaninfection-with-novel-coronavirus-(2019ncov).

2 Huang C, Wang Y, Li X, Ren L, Zhao J, Hu Y, et al. Clinical features of patients infected with 2019 novel coronavirus in Wuhan, China. Lancet. 2020 Feb;395(10223):497-506.

$3 \mathrm{Wu}$ Z, McGoogan JM. Characteristics of and Important Lessons From the Coronavirus Disease 2019 (COVID-19) Outbreak in China: Summary of a Report of 72314 Cases From the Chinese Center for Disease Control and Prevention. JAMA. 2020, Epub ahead of print.

4 Gates B. Responding to Covid-19 - A Oncein-a-Century Pandemic? N Engl J Med. 2020, Epub ahead of print.

5 Hoehl S, Berger A, Kortenbusch M, Cinatl J, Bojkova D, Rabenau $\mathrm{H}$, et al. Evidence of SARS-CoV-2 Infection in Returning Travelers from Wuhan, China. N Engl J Med. 2020, Epub ahead of print.

6 Ronco C, Navalesi P, Vincent JL. Coronavirus epidemic: preparing for extracorporeal organ support in intensive care. Lancet Respir Med. 2020 Mar;8(3):240-1.

7 Morens DM, Daszak P, Taubenberger JK. Escaping Pandora's Box - Another Novel Coronavirus. N Engl J Med. 2020, Epub ahead of print.

8 Yang X, Yu Y, Xu J, Shu H, Xia J, Liu H, et al. Clinical course and outcomes of critically ill patients with SARS-CoV-2 pneumonia in Wuhan, China: a single-centered, retrospective, observational study. Lancet Respir Med. 2020, Epub ahead of print.

9 Gao QY, Chen YX, Fang JY. 2019 novel coronavirus infection and gastrointestinal tract. J Dig Dis. 2020, Epub ahead of print.

10 Young BE, Ong SW, Kalimuddin S, Low JG, Tan SY, Loh J, et al.; Singapore 2019 Novel Coronavirus Outbreak Research Team. Epidemiologic Features and Clinical Course of Patients Infected With SARSCoV-2 in Singapore. JAMA. 2020, Epub ahead of print.

11 Chen N, Zhou M, Dong X, Qu J, Gong F, Han Y, et al. Epidemiological and clinical characteristics of 99 cases of 2019 novel coronavirus pneumonia in Wuhan, China: a descriptive study. Lancet. 2020 Feb; 395(10223):507-13.
12 Ruan Q, Yang K, Wang W, Jiang L, Song J. Clinical predictors of mortality due to COVID-19 based on an analysis of data of 150 patients from Wuhan, China. Intensive Care Med. 2020, Epub ahead of print.

13 Alhogbani T. Acute myocarditis associated with novel Middle east respiratory syndrome coronavirus. Ann Saudi Med. 2016 Jan-Feb; 36(1):78-80.

14 Kotecha A, Vallabhajosyula S, Coville HH, Kashani K. Cardiorenal syndrome in sepsis: A narrative review. J Crit Care. 2018 Feb;43: 122-7.

15 Beutel G, Wiesner O, Eder M, Hafer C, Schneider AS, Kielstein JT, et al. Virus-associated hemophagocytic syndrome as a major contributor to death in patients with 2009 influenza A (H1N1) infection. Crit Care. 2011; 15(2):R80.

16 Brisse E, Wouters CH, Andrei G, Matthys P. How Viruses Contribute to the Pathogenesis of Hemophagocytic Lymphohistiocytosis. Front Immunol. 2017 Sep;8:1102.

17 Bouadma L, Lescure FX, Lucet JC, Yazdanpanah Y, Timsit JF. Severe SARSCoV-2 infections: practical considerations and management strategy for intensivists. Intensive Care Med. 2020, Epub ahead of print.

18 Ronco C, Ricci Z, Husain-Syed F. From Multiple Organ Support Therapy to Extracorporeal Organ Support in Critically Ill Patients. Blood Purif. 2019;48(2):99-105.

19 Brodie D, Vincent JL, Brochard LJ, Combes A, Ferguson ND, Hodgson CL, et al.; International ECMO Network (ECMONet). Research in Extracorporeal Life Support: A Call to Action. Chest. 2018 Apr;153(4):788-91.

20 Husain-Syed F, Ricci Z, Brodie D, Vincent JL, Ranieri VM, Slutsky AS, et al. Extracorporeal organ support (ECOS) in critical illness and acute kidney injury: from native to artificial organ crosstalk. Intensive Care Med. 2018 Sep;44(9):1447-59.

21 Brodie D, Curtis JR, Vincent JL, Bakker J, Brown CE, Creteur J, et al.; participants in the Round Table Conference. Treatment limitations in the era of ECMO. Lancet Respir Med. 2017 Oct;5(10):769-70.

22 Noah MA, Peek GJ, Finney SJ, Griffiths MJ, Harrison DA, Grieve R, et al. Referral to an extracorporeal membrane oxygenation center and mortality among patients with severe 2009 influenza A(H1N1). JAMA. 2011 Oct; 306(15):1659-68.

23 DeLaney E, Smith MJ, Harvey BT, Pelletier KJ, Aquino MP, Stone JM, et al. Extracorpo- real life support for pandemic influenza: the role of extracorporeal membrane oxygenation in pandemic management. J Extra Corpor Technol. 2010 Dec;42(4):268-80.

24 Fitzgerald M, Millar J, Blackwood B, Davies A, Brett SJ, McAuley DF, et al. Extracorporeal carbon dioxide removal for patients with acute respiratory failure secondary to the acute respiratory distress syndrome: a systematic review. Crit Care. 2014 May;18(3): 222.

25 Wendon J, Cordoba J, Dhawan A, Larsen FS, Manns M, Samuel D, et al.; EASL Governing Board representative. EASL Clinical Practical Guidelines on the management of acute (fulminant) liver failure. J Hepatol. 2017 May; 66(5):1047-81.

26 Ankawi G, Fan W, Pomarè Montin D, Lorenzin A, Neri M, Caprara C, et al. A New Series of Sorbent Devices for Multiple Clinical Purposes: Current Evidence and Future Directions. Blood Purif. 2019;47(1-3):94100

27 Poli EC, Rimmelé T, Schneider AG. Hemoadsorption with CytoSorb $^{\circledR}$. Intensive Care Med. 2019 Feb;45(2):236-9.

28 Ankawi G, Xie Y, Yang B, Xie Y, Xie P, Ronco C. What Have We Learned about the Use of Cytosorb Adsorption Columns? Blood Purif. 2019;48(3):196-202.

29 Girardot T, Schneider A, Rimmelé T. Blood Purification Techniques for Sepsis and Septic AKI. Semin Nephrol. 2019 Sep;39(5):505-14.

30 Ronco C, Tetta C, Mariano F, Wratten ML, Bonello $\mathrm{M}$, Bordoni $\mathrm{V}$, et al. Interpreting the mechanisms of continuous renal replacement therapy in sepsis: the peak concentration hypothesis. Artif Organs. 2003 Sep;27(9):792801.

31 Honore PM, Hoste E, Molnár Z, Jacobs R, Joannes-Boyau O, Malbrain ML, et al. Cytokine removal in human septic shock: where are we and where are we going? Ann Intensive Care. 2019 May;9(1):56

32 Rimmelé T, Kellum JA. Clinical review: blood purification for sepsis. Crit Care. 2011;15(1): 205.

33 Reiter K, Bordoni V, Dall'Olio G, Ricatti MG, Soli M, Ruperti S, et al. In vitro removal of therapeutic drugs with a novel adsorbent system. Blood Purif. 2002;20(4):380-8.

34 Koch B, Schult-Dietrich P, Büttner S, Dilmaghani B, Lohmann D, Baer PC, et al. Lectin Affinity Plasmapheresis for Middle East Respiratory Syndrome-Coronavirus and Marburg Virus Glycoprotein Elimination. Blood Purif. 2018;46(2):126-33. 